\title{
INTEGRASI METODE SIX SIGMA KE DALAM PROGRAM PEMBELAJARAN TEACHING FACTORY SEBAGAI UPAYA PENINGKATAN MUTU PESERTA DIDIK
}

\author{
Sheila Fransisca Fortunata' \\ Agus Timan ${ }^{2}$ \\ Achmad Supriyanto ${ }^{3}$ \\ ${ }^{123}$ Universitas Negeri Malang, Jalan Semarang No. 5 Malang \\ 'Email : fransisca.cheila@gmail.com
}

\begin{abstract}
The aims of this article aims to analyze the teaching factory learning program as an effort to improve the quality of students who try to be integrated using the Six Sigma method as one of the development of Total Quality Management (TQM) in SMK 3 Malang. The method used in writing this article is by elaborating the results of interviews and observations and related literature studies. The results of the analysis show that while the school context does not explain that it has applied the concept of TQM. From the stages of implementing the six sigma method it can be said that this school has implemented the six sigma method in planning activities until its implementation. With the integration of the six sigma method into school programs, schools can be said to have a quality culture for creating quality schools.
\end{abstract}

Keywords: Teaching Factory, improving the quality of students, the concept of TQM, Six Sigma

Abstrak: Penulisan artikel ini bertujuan untuk menganalisis program pembelajaran teaching factory sebagai salah satu upaya peningkatan mutu peserta didik yang mencoba diintegrasikan dengan menggunakan metode Six Sigma sebagai salah satu pengembangan dari Total Quality Management (TQM). Metode yang digunakan dalam penulisan artikel ini adalah dengan penjabaran hasil wawancara dan observasi dan kajian literatur terkait. Hasil dari analisis menunjukan bahwa seara konteks sekolah tidak menjelaskan bahwa telah menerapkan konsep dari TQM. Dari tahapan pelaksanaan metode six sigma dapat dikatakan sekolah ini sudah menerapkan metode six sigma dalam kegiatan perencanaan hingga implementasinya. Dengan adanya integrasi metode six sigma ke dalam program sekolah, maka sekolah dapat dikatakan memiliki budaya mutu untuk menciptakan sekolah yang bermutu.

Kata Kunci: Teaching Factory, peningkatan mutu peserta didik, konsep TQM, Six Sigma

\section{PENDAHULUAN}

Tahun 2013, peringkat mutu sumber daya manusia Indonesia berada di tingkat 108. Berada jauh dibawah Malaysia (62) dan Singapura (12) berdasarkan Human Deveopment Report, (Kemendikbud, 2016). Selain itu, World Economic Forum menyatan daya saing global di Indonesia di tahun 2014 menduduki tingkat 34 dibawah Thailand (3I) dan Korea Selatan 26). Di tahun berikutnya, Indonesia mengalami penurunan menjadi peringkat 37 dalam persaingan global. Data dari Badan Pusat Statistik (BPS) juga mencatat bahwa pada tahun 2014 masih terdapat 7,24 juta orang pengangguran atau 5,94\% dari total angkatan kerja.

Salah satu lembaga pendidikan formal yang mencetak lulusannya untuk siap terjun ke dunia kerja yaitu Sekolah Menengah Kejuruan (SMK). Meningkatnya persaingan global yang terjadi saat ini mengharuskan SMK berkembang mengikuti arah perkembangan dunia kerja, langkah yang dapat ditempuh dengan membuka atau mempertajam kompetensi keahlian yang ada dengan mempertimbangkan relevansi terhadap tuntutan dunia kerja (DU/ DI). Program revitalisasi yang dilaksanakan oleh SMK percontohan meliputi (I) Pengembangan dan 
penyelarasan kurikulum dengan DUDI; (2) Pembelajaran yang diinovasikan untuk mengembangkan ketrampilan; (3) Pemenuhan dan peningkatan profesionalitas guru dan tenaga kependidikan; (4) Pemenuhan standar sarana dan prasarana, pembaruan program kerja sama dengan industri; (5) Manajemen lembaga; dan (6) Peningkatan akses sertifikasi kompetensi.

Kurikulum SMK memiliki karakter yang mengarah kepada pembentukan kompetensi lulusan berkaitan dengan pelaksanaan tugas pekerjaan tertentu. Inti kompetensi kejuruan didapatkan pada kurikulum program produktif dengan dilandasi dasar keilmuan pada program adaptif, dan nilai-nilai pada program normatif. Sehingga diharapkan pengembangan kurikulum yang disusun sekolah akan berdampak pada kompetensi peserta didik. Peyusunan kurikulum ini didasarkan pada kebutuhan dunia industri yang bekerjasama dengan sekolah dan juga dunia industri lain dengan menyamakan kompetensi antara kurikulum pusat dengan kurikulum industri.

Perbaikan dan penyelerasan kurikulum SMK akan memantapkan model kesesuaian dan keterkaitan (link and match) dengan DUDI. Kurikulum dirancang dengan berorientasi pada penggabungan antara instruction dan construction sehingga pendekatan utama dalam membentuk tahapan pembelajaran yang mengacu pada fase pembelajaran di sekolah ataupun praktik di industri dan berorientasi pada hasil proses pembelajaran yang diinginkan. Saat ini pemerintah melakukan penyelarasan kurikulum SMK yang mencakup pengembangan SMK 4 tahun yang memiliki nama kompetensi dan standar kompetensi lulusan (SKL) yang berbeda dengan SMK 3 tahun.

Peningkatan relevansi SMK dengan DU/DI sejalan dengan tujuan SMK dalam penjelasan pasal 15 UU Sisdiknas No.20 Tahun 2003, yaitu SMK sebagai "Pendidikan menengah yang mempersiapkan peserta didik terutama untuk bekerja dalam bidang tertentu". Sejalan dengan hal itu, Purwana (2010) merumuskan Tujuan SMK menurut BSNP yaitu "untuk meningkatkan kecerdasan, pengetahuan, kepribadian, akhlak mulia, serta keterampilan hidup mandiri dan mengikuti pendidikan lebih lanjut sesuai dengan kejuruannya”.

Pentingnya kurikulum SMK relevan dengan dunia kerja, disebabkan banyaknya kritikan terhadap mutu lulusan SMK, kondisi tersebut dituliskan As'ari (2003) bahwa "peta kompetensi SMK sering dikritik karena tidak luwes terhadap perubahan, memiliki keterampilan tunggal yang cepat usang, dan tidak mampu mengembangkan dirinya". Hal ini dilatarbelakangi kenyataan bahwa implementasi kurikulum belum sesuai dengan harapan, belum optimalnya guru-guru mentransmisikan kompetensi kejuruan yang harus dikuasai siswa sesuai dengan kompetensi keahliannya, dan pengelolaan pembelajaran yang pada umumnya belum mendasarkan pada sistem diklat di SMK berbasis kompetensi.

Kondisi DU/DI saat ini belum dapat mendukung terlaksananya sistem pendidikan begitu juga sebaliknya, (Hidayat, 20II). Pelaksanaan praktik kerja industri (prakerin) juga dirasa kurang mampu mengembangkan potensi peserta didik di dunia kerja. Dengan permasalahan dan hambatan yang dikemukakan, disarankan adanya model pembelajaran yang dapat mengatasi permasalahan missmatching antara dunia pendidikan dan DU/DI.

Memperhatikan hal-hal tersebut di atas, model teaching factory dianggap cocok diterapkan di SMK. Model pembelajaran teaching factory berdasar pada fokus Kurikulum Tingkat Satuan Pendidikan (KTSP) 2006. Model pembelajaran ini berbasis pada pengintegrasian pendidikan dan dunia kerja yang meliputi (I) Pembelajaran berbasis produksi; (2) Dukungan akan pentingnya peningkatan mutu pendidikan; dan (3) Berorientasi pada kerjasama yang baik antara sekolah dengan DU/DI. Selain itu beberapa pandangan lain dengan diterapkannya teaching factory di SMK yaitu semakin membengkaknya bahan paraktik peserta didik, perawatan perlatan penunjang pembelajaran yang tidak murah, dan menimbulkan kepercayaan diri serta kebanggan pada lulusan. (Hidayat, 20II). Teaching factory ialah pembelajaran yang dikembangkan oleh sekolah kejuruan sebagai upaya meningkatkan kompetensi peserta didik melalui pembelajaran dengan praktik atau produksi, (Nurtanto, dkk, 20l7). 
Pembelajaran dengan teaching factory memiliki tujuan untuk mengembangkan dan menumbuhkan etos kerja yang dibutuhkan dalam dunia kerja yaitu disiplin, tanggungjawab, jujur, kerjasama, kepemimpinan). Serta, dengan pembelajaran teaching factory akan menigkatkan mutu hasil belajar dari sekedar hasil kompetensi menuju ke pembelajaran yang memberikan kemampuan memproduksi barang/jasa, (Skaneda, 2018). Tidak hanya meningkatkan mutu peserta didik, namun dengan adanya pembelajaran teaching factory ini dapat menjalin hubungan kerjasama dan komunikasi yang baik dengan DU/DI dalam pola pmebelajarannya. Pembelajaran teaching factory memiliki dampak positif agar kerjasama yang dijalin dapat berjalan dengan sistematis dan terencana. Keuntungan lain dengan menerapkan pembelajaran teaching factory ini adalah terjadinya check and balance terhadap proses pendidikan di SMK untuk menstabilkan dan memelihara keselarasan (link and match) dengan kebutuhan pasar kerja.

Sekolah yang berlokasi di kecamatan Klojen Kota Malang sebagai salah satu SMKN yang menerapkan pembelajaran teaching factory. Lembaga pendidikan ini menjadi salah satu sekolah yang menerapkan pembelajaran teaching factory sebagai upaya peningkatan mutu peserta didiknya. sekolah juga merupakan sekolah yang berhasil menerapkan pembelajaran teaching factory. Tentunya dalam meningkatkan mutu peserta didiknya, pemenuhan standar akreditasi saja dirasa belum cukup. Sekolah harus terus menerus mengembangkan dirinya untuk mencapai tujuan mutu yang diinginkan. Strategi yang digunakan salah satunya yaitu dengan pendekatan Total Quality Management (TQM). TQM melibatkan dan memberdayakan orangorang yang berada di dalam organisasi guna meningkatkan mutu secara berkelanjutan. (Sallis, 2006). Crosby dalam Farooq (2007) menjelaskan bahwa TQM dapat dilakukan dalam bidang pendidikan dengan meningkatkan sistem pengajaran. TQM tidak dapat dicapai tanpa ada komitmen untuk mencapai tujuan yang disepakati dengan kinerja yang maksimal, Kaufman (1992).

Metode untuk meningkatkan kualitas atau mutu lembaga salah satunya adalah melalui Six Sigma. Metode ini digunakan untuk meningkatkan mutu yang terfokus pada kepuasan pelanggan mengikuti model formal yaitu Define, Measure, Analyze, Improve, Control (DMAIC) dan dikaitkan dengan dunia pendidikan. Menurut Crosby dalam Farooq (2007), peningkatan mutu di dunia pendidikan yaitu melalui peningkatan sistem pengajaran. Perbaikan di setiap program sekolah yang dilaksanakan dengan melibatkan seluruh warga sekolah, termasuk para stake holder, wali murid, dan masyarakat.

Berdasarkan penjelasan tersebut, penulisan artikel ini bertujuan untuk menganalisis apakah selain pembelajaran teaching factory sebagai salah satu upaya peningkatan mutu peserta didik, sekolah ini sudah menerapkan prinsip-prinsip TQM dalam proses peningkatan mutu. Sebagai tambahan, dalam artikel ini juga dipaparkan mengenai bagaimana jika strategi Six Sigma diintegrasikan ke dalam pembelajaran teaching factory di sekolah ini.

\section{Konsep Mutu dalam Pendidikan}

Sallis (2006), mengemukakan pandangannya terkait TQM. Menurutnya, TQM adalah sebuah filosofi tentang perbaikan secara terus menerus, yang dapat memberikan seperangkat alat praktis kepada setiap institusi pendidikan dalam memenuhi kebutuhan, keinginan, dan harapan para pelanggannya setiap periode waktu. "TQM a philosophy and set of guilding principles that represent the foundation of a continuosly improving organization". TQM dianggap menjadi suatu landasan yang memberikan pengaruh cukup besar terhadap organisasi (sekolah) guna meghadapi perubahan-perubahan yang terus meningkat sesuai kebutuhan masyarakat. Semua sumberdaya yang ada di sekolah diintegrasikan dengan pelaksanaan manajemen, seperti perencanaan, persiapan pelaksanaan teknis yang efektif dan efisien. Sehingga produk yang dihasilkan bermanfaat untuk masyarakat, Nawawi (2005).

TQM merupakan salah satu cara meningkatkan kualitas suaru organisasi (sekolah) sebagai suatu komoditas yang dapat diukur untuk meningkatkan dan menilai hasil dari pelaksanaan program dan seluruh kegiatan yang dilakukan oleh sekolah. TQM memperbaiki 
kualitas pendidikan dengan mempertimbangkan aspek (I) Input yaitu peserta didik, staf, guru, keuangan; (2) Proses yaitu pembelajaran dan pelatihan; (3) Output yaitu kepuasan, kecerdasan, perubahan; dan (4) Outcomes yaitu mendapatkan pekerjaan, menjadi manusia positif dikalangan masyarakat.

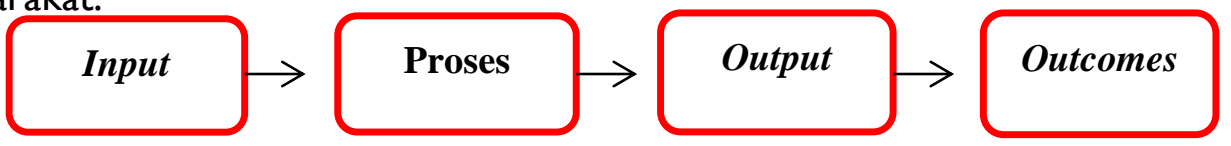

Konsep mutu dari Sallis (2006) secara garis besar memaparkan ada beberapa hal penting yang berkaitan dengan mutu yaitu (I) Kesesuaian produk dengan spesifikasi standar yang ditetapkan perusahaan; (2) Memenuhi kepuasan pelanggan; (3) Perbaikan secara kontinyu dan pelibatan seluruh anggota; dan (4) Perubahan budaya dan komitmen untuk terus meningkatkan mutu. Pertama, kesesuaian produk dengan spesifikasi standar yang ditetapkan perusahaan. Kesesuaian hasil produk dan jasa dengan standar yang telah ditetapkan, maka produk dan jasa tersebut bisa dikatakan bermutu. Bila dihubungkan dengan dunia pendidikan, outcome peserta didik yang dihasilkan oleh sekolah disarankan untuk menghasilkan peserta didik yang dapat bersaing di dunia kerja serta membuka lapangan kerja.

Kedua, memenuhi kepuasan pelanggan. Kualitas atau mutu untuk memenuhi kepuasan pelanggan atau dengan kata lain customer oriented. Dari pernyataan tersebut, dalam konsep mutu pelanggan/customer menjadi yang utama. Pemenuhan kebutuhan dan keinginan pelanggan menjadi fokus dalam peningkatan mutu. Produk atau jasa yang dihasilkan oleh organisasi haru sesuai dengan kebutuhan. Kaitannya dengan dunia pendidikan, sekolah terutama SMK dalam pembahasan ini harus dapat memenuhi kepuasan pelanggan internal dan eksternal. Pelanggan internal yaitu peserta didik itu sendiri, guru dan staf sekolah. Pelanggan eksternal yaitu masyarakat, perusahaan, stake holder,dan pihak lain yang bekerjasama dengan sekolah.

Ketiga, perbaikan secara kontinyu dan pelibatan seluruh anggota. Perbaikan secara terus menerus atau kontinyu merupakan salah satu prinsip yang dapat diterapkan dalam mengimplementasikan mutu. Dalam konsep mutu, perbaikan secara terus menerus memilki dampak yang positif bagi organisasi. Untuk itu, pelibatan seluruh anggota sangat diperlukan untuk mendukung peningkatan mutu organisasi. Keterlibatan anggota internal dan eksternal yang terpadu, dapat memperbaiki dan meningkatkan mutu organisasi

Keempat, perubahan budaya dan komitmen untuk terus meningkatkan mutu. Peningkatan mutu di organisasi dapat mengakibatkan perubahan budaya dan komitmen para anggota untuk meningkatkan mutu organisasi. Dikaitkan dengan dunia pendidikan, perubahan budaya dan komitmen warga sekolah perlu dikoordinir dan dimulai oleh kepala sekolah. Sebagai pemimpin, kepala sekolah berusaha untuk meningkatkan mutu sekolah yang dapat dilakukan melalui kebijakan, program kerja, dan pembiasaan.

\section{Six Sigma}

Six sigma sebagai metode yang dapat digunakan untuk meningkatkan mutu. Six sigma merupakan suatu langkah konkrit yang dapat digunakan sebagai alat dengan memfasilitasi untuk menganalisis data secara statistik ataupun yang lain (Anderson et all, 2006). Six sigma juga dapat diartikan sebagai "a collection of process improvement tools used in a series of projects in a systematic way to achieve high levels of stability. It is based on principles set up by quality experts, such as Deming, Juran, Shewart and Ishakawa". Yang dapat diartikan bahwa six sigma merupakan alat untuk perbaikan yang dirancang dalam serangkaian kegiatanatau program untuk mencapai standar yang diinginkan. Hal ini didasarkan pada prinsip dan teori dari Deming, Juran, Shewart, dan Ishikawa (Salah dan Carretero, 2009).

Six sigma digunakan sebagai alat perbaikan di perusahaan Motorola. Hal ini dilakukan pada perusahaan Motorola yang memproduksi banyak produk dengan komponen elektronik dengan ribuan kesempatan untuk gagal karena banyaknya komponen yang terlibat. Motorola berhasil mencapai target minimalisasi produk cacat sehingga peluang untuk gagal menjadi 
rendah. Program Six Sigma Quality Motorola diimplementasikan di tahun 1987 yang dipelopori oleh B. Smith (Devane, 2004). Kemudian six sigma dikembangkan lagi untuk meningkatkan keandalan dan kualitas produk.

Proses implementasi six sigma dimulai dengan mengidentifikasi kebutuhan untuk tujuan dan target peningkatan mutu. Ketika proses jalannya six sigma dimulai, analisiskeuangan juga harus direncanakan, dengan mengukur efektifitas besarnnya biaya yang dikeluarkan dengan target capaian. Six sigma digunakan untuk membantu perusahaan meminimalisir kegagalan, mengurangi biaya operasional dan meningkatkan kebutuhan dan kepuasan pelanggan. Six sigma dapat berhasil bergantung pada kekuatan pemimpin (Antony, 2006). Implementasi yang terstruktur dan dukungan pemimpin akan sangat penting guna keberhasilan six sigma. Ada beberapa prinsip six sigma yang dikemukakan oleh Stroud dan Sutterfield (2007) yaitu sebagai berikut: (I) Keselarasan proses dan kebutuhan pelanggan dengan tujuan strategi perusahaan; (2) Mengidentifikasi tujuan utama program, sumber daya yang dibutuhkan, rencana pemecahan masalah; (3) Menciptakan standar pengukuran; dan (4) Mengadakan pelatihan, pemberdayaan anggota organisasi, dan menetapkan pengembangan tujuan.

Selain itu, ada langkah-langkah proses six sigma yang dipaparkan oleh Salah dan Carretero (2009) yaitu phases of measure, analyze phases, improve phases, and control phases. Kemudian dikembangkan oleh Dahlgaard (2006) yaitu define, measure, analyze, improve, and control (DMAIC) sebagai pengembangan siklus PDCA Deming. Sebagai jabarannya sebagai berikut: Define, sebagai fase menentukan masalah, menetapkan kebutuhan dan keinginan pelanggan (voice of customers), dan memberdayakan anggota organisasi. Dalam tahap ini belum banyak memerlukan data statistik, tools ataupun diagram. Alat yang dapat digunakan yaitu cause effect chart atau diagra pareto. Kedua tools ini digunakan untuk mengidentifikasi dan menentukan prioritas permasalahan.

Measure, fase pengukuran dengan menentukan standar variasi produk dan variasi pengukuran kegagalan produk yang dihasilkan. Penetapan standar yang digunakan untuk setiap variasi yang ada. Analyze, merupakan fase untuk menentukan penyebab dari masalah yang ada dengan menggunakan beberapa tools mutu antara lain diagram pareto dan cause and effect chart. Yang kemudian dikelompokan dan menghasilkan suatu dasar timbulnya suatu masalah. Improve, fase pengembangan untuk meningkatkan target atau tujuan dengan berusaha untuk meminimalisir atau menghilangkan penyebab kegagalan produk. Pada fase pengembangan ini melibatkan uji percobaan, sehingga diketahui penyebab perubahan atau kegagalan yang dialami. Control, fase pengawasan ini dilakukan untuk memonitoring kinerja dan menjamin tidak adanya kegagalan yang terjadi. Hal yang dilakukan dalam kontrol ini adalah membantu mengurangi penyebab kegagalan, memonitor kinerja anggota, dan proses koreksi.

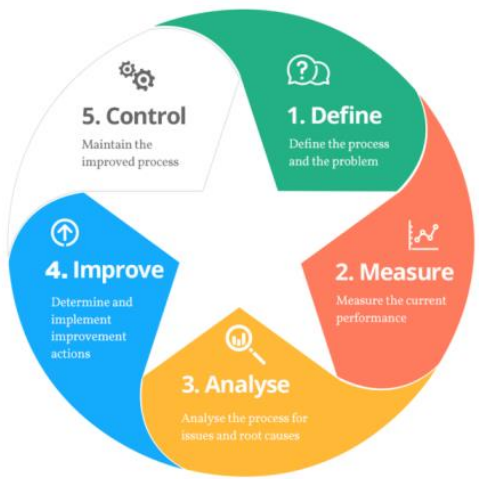

Gambar I. DMAIC

Six sigma yag dikemukakan di atas merupakan langkah-langkah dan implementasi six sigma di perusahaan atau pabrik. Jika dikaitkan di dunia pendidikan maka berbeda dalam pengimplementasiannya. Six sigma pada awalnya dianggap tidak cocok untuk diterapkan di 
dunia pendidikan. Di lembaga pendidikan tidak memiliki standar yang ditentukan dala metode six sigma seperti peralatan produksi, input, output, dan inventaris. Begitu pula sebaliknya, pendidikan berkaitan dengan manusia yang sulit diprediksi dan tidak sama dengan produksi. Pendidikan lebih pada pembelajaran, kinerja dan kepuasan peserta didik (Villanova, 20I5).

Banyak manfaat yang dapat diambil dari penerapan six sigma di pendidikan. Pendidikan sendiri memiliki proses berulang yang juga terdapat pada prinsip six sigma. Sama halnya dengan six sigma, pendidikan berfokus pada kebutuhan dan kepuasan peserta didik. Penyesuaian six sigma dengan pendidikan berlaku pada outcomes peserta didik saat berada di persaingan global saat ini yang diwajibkan mencetak peserta didik yang unggul dan memiliki kinerja tinggi. Oleh karena itu, six sigma dapat digunakan di lembaga pendidikan guna meningkatkan mutu peserta didik.

Tidak semua substansi dalam organisasi pendidikan atau lembaga pendidikan dapat diterapkan metode six sigma. Ada beberapa substansi yang cocok yaitu (I)Administrasi, prinsip six sigma yang dapat mengurangi atau meminimalisir kesalahan sangat cocok digunakan agar proses adinistrasi di sekolah tersebut berjalan lancar. Prinsip six sigma yang dapat meminimalisir kesalahan tersebut bisa melalui prosedur penerimaan berkas, penggunaan teknologi informasi dalam setiap kegiatan adiministrasi, kemudahan sertifikasi, penanganan pengeluaran dan pemasukan dana; (2) Pendaftaran, guna meningkatkan antusias dan kepuasan pelanggan (peserta didik) dalam tahap pendaftarn di sekolah six sigma cocok diterapkan untuk mempersiapkan segala hal yang berkaitan dengan kenyamanan, kelancaran, dan kemudahan mendaftar; dan (3) Akademik, dalam bagian ini six sigma dapat berperan aktif untuk meningkatkan kemampuan peserta didik. Dimulai dari menciptakan suatu masalah, menentukan prosesnya, memecahkan masalahnya, dan membuat tolak ukur atau standar yang diperlukan untuk penilaian.

Berdasarkan paparan di atas, six sigma dipandang sebagai suatu metode yang dapat meningkatkan mutu. Paparan di atas menunjukan bahwa TQM dan six sigma sama-sama berfokus pada kepuasan pelanggan (voice of customer).

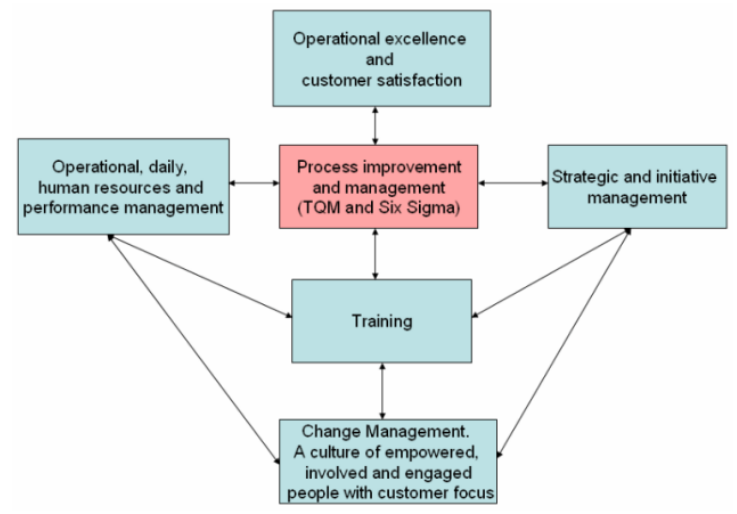

Gambar 2. Integrated Framework of TQM and Six Sigma

Six sigma dianggap sebagai suatu pengembangan dari TQM oleh 6sigma (20I8) dengan meminimalisir biaya, berfokus pada penggunaan tools untuk pencapaian target, memadukan seluruh tujuan organisasi, dan menciptakan komitmen perubahan pada kinerja dan hasil. Metode six sigma dapat digunakan dalam sektor pendidikan sehingga memungkinkan lemabaga pendidikan (sekolah) dapat menerapkan metode sebagai salah satu upaya meningkatkan mutu peserta didiknya.

\section{METODE PENELITIAN}

Metode yang digunakan dalam penulisan artikel ini adalah analisis program pembelajaran teaching factory dan mencoba mengintegrasikan Six Sigma ke dalam sistem sekolah yang disandingkan dengan program pembelajaran teaching factory. Penulisan artikel ini 
didasarkan pada hasil wawancara dilakukan oleh peneliti dengan Ibu Toliah selaku Waka Kurikulum di SMK Negeri 3 Malang, yang selanjutnya dianalisis menggunakan kajian literatur yang ada.

\section{HASIL DAN PEMBAHASAN \\ Hasil}

Berdasarkan wawancara dan observasi yang dilakukan, hasilnya indikator penerapan TQM di sekolah dilihat dari keselarasan dengan standar yang telah ditetapkan dan mapu memenuhi kebutuhan dan kepuasan pelanggan. Selanjutnya, penjelasan six sigma yang terdiri dari Define, Measure, Analyze, Improve, dan Control.

Bila dihubungkan dengan sekolah yang menggunakan program pembelajaran teaching factory sebagai salah satu standar peningkatan mutu peserta didik. Indkator penerapan TQM di sekolah ini adalah dengan mampunya sekolah untuk memenuhi kebutuhan pelanggan. Mampu memenuhi kebutuhan pelanggan yang berpedoman pada kepuasan pelanggan yang ada di sekolah. Meskipun tidak dalam jumlah yang signifikan, penerapan program pembelajaran teaching factory berdampak positif pada meningkatnya kemampuan peserta didik. Selain itu, kepuasan pelanggan tidak hanya pada peserta didik namun juga pada pihak perusahaan yang merekrut para lulusan dan perusahaan yang bekerjasama dengan sekolah untuk progra pembelajaran.

Hasil analisis selanjutnya adalah pada metode six sigma yang memiliki lima poin utama yaitu Define, Measure, Analyze, Improve, dan Control (DMAIC). Define, adalah poin pertama dari metode six sigma yang berfokus pada penentuan prioritas masalah baik internal ataupun eksternal. Secara umum, pada fase ini juga sebagai penetapan target atau tujuan dan pemberdayaan anggota organisasi. Indikator pertama, fokus pelanggan dipandang dari analisis kebutuhan sekolah yang dilakukan secara periodik melalui Evaluasi Diri Sekolah (EDS) berguna untuk mengetahui kebutuhan pelanggan. Hasil dari EDS ini dapat dijadikan pedoman dan bahan untuk penyusunan program-program sekolah. Penentuan sebab kurangnya lulusan yang bisa bersaing di dunia kerja yaitu kurangnya pembelajaran praktik. Pendidikan Kerja Lapangan (PKL) yang dijalani oleh peserta didik dirasa belum cukup untuk meningkatkan kemapuan peserta didik di duniakerja. Maka prioritas utama yaitu dengan mengembangkan pembelajaran melalui program pembelajaran teaching factory.

Poin kedua, yaitu measure. Fase pengukuran dengan menentukan standar keberhasilan pembelajaran dan lulusan yang diterimadi duniakerja yang digunakan untuk program pembelajaran teachng factory. Sekolah juga memiliki standar kelulusan yang tetap mengacu pada standar yang ditetapkan oleh pemerintah pusat dan dikembangkan dengan tuntutan standar dari perusahaan (dunia kerja). Penetapan standar ini dilakukan dengan mengamati peserta didik mulai dari kelas XI untuk dijadikan peserta didik pilihan yang dianggap mapu masuk kelas teaching factory. Kemudian, pada saat kelas XI peserta didik tersebut diarahkan untuk penjurusan dalam kelas teaching factory. Hasil capaian yang diperoleh yaitu dari produk yang dihasilkan peserta didik yang sudah memenuhi standar dunia industri. Tentunya, peserta didik reguler dan peserta didik dengan teaching factory memiliki kemampuan yang berbeda

Selanjutnya, analyze merupakan fase untuk menentukan penyebab dari masalah yang ada dengan menggunakan beberapa tools mutu. Sekolah melakukan analisis permasalahan melalui evaluasi secara kelompok yang dipimpin oleh kepala sekolah. Analisis dilakukan melalui diskusi dan rapat secara berkelanjutan untuk mengusut kekurangan dan penyebab dari adanya masalah. Yang kemudian ditindaklanjuti dengan tindakan evaluasi sebagai upaya perbaikan. Peran kepala sekolah dalam fase ini yaitu sebagai narasumber untuk diskusi yang dilakukan seluruh anggota organisasi. Selain itu, guru dan staf juga ikut berpartisipasi dalam diskusi dan analisis yang dilakukan sesuai dengan keadaan dilapangan (kelas) dan lingkungan. Tidak hanya itu, analisis kebutuhan melalui analisis SWOT juga dilakukan oleh sekolah untuk menentukan 
akar dari masalah yang ada serta pemecahannya. Dari paparan tersebut, sekolah melakukan analisis permasalahan dan kebutuhan untuk keberhasilan pembelajaran.

Poin selanjutnya yaitu improve. Pengembangan untuk meningkatkan target atau tujuan dengan berusaha untuk meminimalisir penyebab kegagalan. Pengembangan pembelajaran yang terintegrasi dengan kebutuhan industri dapat dilakukan oleh sekolah dengan proporsi dan komposisi yang sesuai. Koordinasi dengan perusahaan kerjasama untuk menentukan Kompetensi Inti dan Kompetensi Dasar (KI/KD) dalam penyusunan kurikulum. Kegiatan ini dilakukan sebelum dimulainya tahun ajaran baru dengan melakukan rapat dan diskusi dengan perusahaan untuk sinkronisasi KI/KD kurikulum sekolah. Pengembangan KI/KD yang dilakukan sekolah juga tidak terlepas dari peran Waka Humas. Tugas dari Waka Humas tersebut adalah membuat atau mengirim MoU dari sekolah ke perusahaan untuk menjalin kerjasama. MoU ini berisikan kerjasama untuk mendiskusikan KI/KD yang sesuai dengan perusahaan ataupun kerjasama untuk relasi pekerjaan. Hubungan kerjasama ini dilakukan dengan berkolaborasi dengan Sevencols (tata busana), L'Oreal (kecantikan), dan hotel-hotel di Malang (perhotelan). Hubungan kerjasama ini tidak hanya untuk pengintegrasian kurikulum dengan dunia industri, tetapi juga ada sebagai tamu untuk acara-acara penting sekolah.

Selain berfokus pada pembelajaran, hal lain yang juga menjadi faktor penting untuk penerapan pembelajaran teaching factory adalah ketersediaan sarana dan prasarana. Penyesuaian sarana prasarana dilakukan pertama melalui meninjau standar sarana dan prasarana yang telah ditetapkan pemerintah lalu kemudian pihak SMK akan mengadopsi dan melakukan penyesuaian dengan kebutuhan yang ada disekolahnya. Seperti pada pembaharuan tahun ajaran ini terdapat penambahan kelas yakni untuk program perhotelan di tambahkan kelas khusus untuk room boy dan pada kelas tata kecantikan di tambah kelas L'Oreal. Penyesuaian media pembelajaran yang dilakukan di SMK Negeri 3 dilakukan dengan mengikuti pengembangan kompetensi keahlian yang telah disusun melalui rapat pembaharuan kurikulum bersama semua pihak baik pihak sekolah, komite dan pihak DU/DI.

Poin terakhir yaitu control, fase pengawasan ini dilakukan untuk memonitoring kinerja dan menjamin tidak adanya kegagalan yang terjadi. Hal yang dilakukan dalam kontrol ini adalah membantu mengurangi penyebab kegagalan, memonitor kinerja anggota, dan proses koreksi. Dalam penintegrasian kurikulum sekolah dengan tuntutan dunia kerja yang khususnya dalam pembelajaran di sekolah memiliki banyak kendala yang dihadapi. Kendala tersebut antara lain penambahan kompetensi keahlian dari perusahaan dan kurikulum dari pusat yang belum mencakup keseluruhan kompetensi yang memenuhi standar perusahaan. Pengawasan dilakukan oleh kepala sekolah, ketua jurusan, dan pengawas sekolah dengan standar yang telah ditetapkan. Pengawasan yang dilakukan secara periodik untuk menghasilkan data yang nyata sebagai bahan evaluasi selanjutnya.

\section{Pembahasan}

Sekolah menggunakan program pembelajaran teaching factory sebagai peningkatan mutu peserta didik. Artinya, sekolah tidak hanya memenuhi standar akreditasi yang ditentukan oleh pemerintah, di sisi lain sekolah juga menambah standar akreditasi peserta didik dengan menerapkan program pembelajaran peserta didik. Dengan adanya progra pembelajaran teaching factory ini sekolah berusaha untuk memenuhi kebutuhan dan kepuasan pelanggan. Pelanggan dala hal ini adalah pelanggan internal dan eksternal sekolah yang masing-masing memiliki indikator keberhasilan sendiri untuk mutu yang diinginkan. Dengan harapan progra pendidikan di SMK benar-benar berorientasi pada kebutuhan masyarakat.

Program pembelajaran teaching factory yang diterapkan oleh sekolah memang ditujukan untuk meningkatkan mutu atau kualitas dari peserta didik khususnya di SMK. Tujuan teaching factory secara umum yaitu untuk mengembangkan kemandirian dan percaya diri peserta didik untuk dapat bersaing di duni kerja melalui pembelajaran berbasis produksi. Hal ini juga menunjukkan bahwa prinsip belajar yaitu learning by doing sangat diperlukan untuk efektivitas 
pendidikan guna menumbuhkan kompetensi (skill) dan kreativitas peserta didik (Kemendikbud, 2016). Pendidikan kejuruan dianggap berhasil jika peserta didik mapu memahami situasi nyata dan peningkatan kompetensi keahlian industri yang nantinya akan menjadi tempat peserta didik tersebut bekerja (Kemendikbud, 20I5).

Program pembelajaran teaching factory yang digunakan sebagai salah satu upaya untuk meningkatkan mutu peserta didik, hal-hal yang sangat mungkin terjadi yaitu masalah yang timbul yang mengakibatkan terhabatnya pelaksanaan teaching factory. Sekolah bisa merencanakan pemecahan masalah melalui tahap atau fase improve untuk meminimalisir kegagalan program. Acuan yang digunakan tentunya tidak terlepas dari standar mutu yang ditetapkan oleh pemerintah.

Bila dipandang dari analisis, manajemen sekolah secara umum sudah menerapkan beberapa poin atau indikator dari six sigma. Hasil analisis wawancara menunjukan bahwa sekolah dalam konteks tidak secara gamblang mengguanakan metode six sigma tersebut, namun secara tersirat tahap-tahap yang dilalui sekolah dalam penerapan progra pembelajaran teaching factory dapat dikatakan sudah sesuai prosedur dari metode six sigma. Contohnya yaitu (I) Mengutamakan kepuasan pelanggan; (2) Mengidentifikasi masalah dan menentukan prioritaspengembangan; (3) Menetapkan standar pengukuran untuk penilaian keberhasilan program; (4) Penggunaan tools mutu dengan evaluasi berkelanjutan yang dilakukan oleh kepala sekolah, guru, staf, komite sekolah, dan perusahaan kerjasama untuk bersama-sama menganalisis masalah-masalah yang mungkin timbul saat pelaksanaan; (5) Mengembangkan program dengan yang berkaitan dengan peningkatan mutu seperti pengembangan $\mathrm{KI} / \mathrm{KD}$ dalam kurikulum, menjalin kerjasama yang baik dengan perusahaan (dunia industri), dan penyediaan sarana dan prasarana yang memadai; dan (6) Melakukan pengawasan dan kontrol terhadap masalah yang timbul, sehingga sesegera mungkin ditanggulangi dan direncanakan sebagai bahan evaluasi.

Jika sekolah mampu mengintegrasikan metode six sigma ke dalam proses sekolah untuk mencapai mutu peserta didik yang diinginkan, maka dapat dikatakan bahwa sekolah mampu meningkatkan mutu dan benar-benar memperbaiki sistem pendidikan di sekolah tersebut. Lebih jelasnya dapat dilihat dalam gambar berikut.

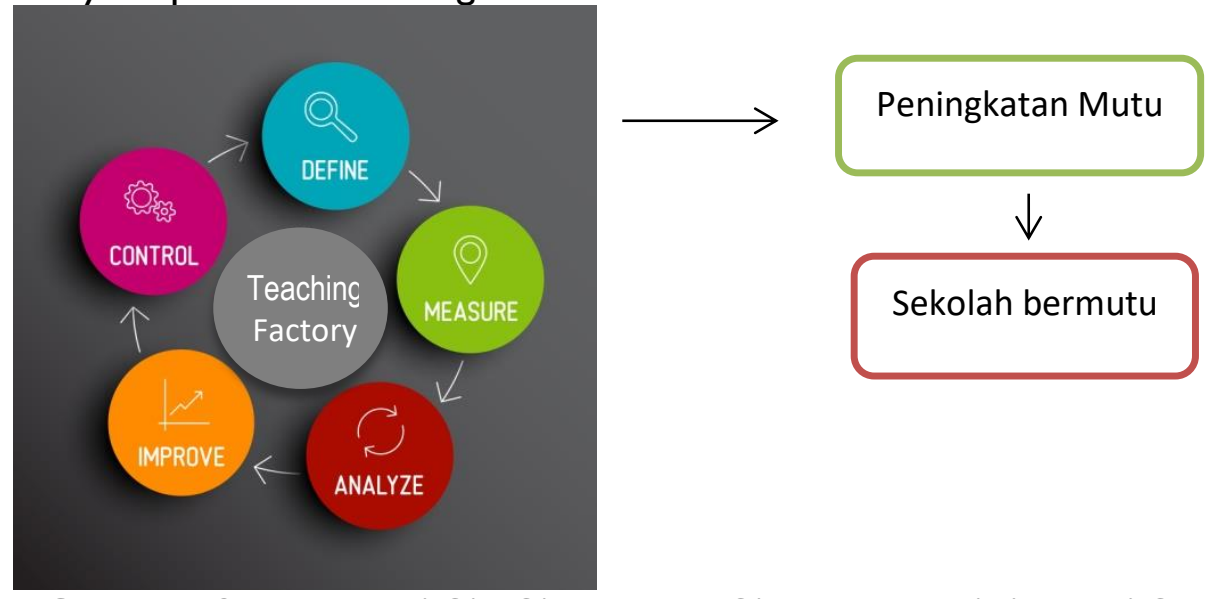

\section{Gambar 3. Integrasi Six Sigma dan Sistem Pendidikan di Sekolah}

Sekolah sebagai suatu sistem dan organisasi yang tidak bisa terlepas dari keterlibatan seluruh anggota organisasi untuk memenuhi kebutuhan pelanggan dan mencapai tujuan mutuyang diinginkan. Sebagai suatu organisasi, sekolah juga memiliki lingkungan yang memiliki pengaruh yang signifikan dengan sistem pendidikan di sekolah tersebut. Lingkungan tersebut termasuk dalam pelanggan internal dan eksternal. Sehingga, peningkatan mutu peserta didik tidak hanya berlaku untuk kepela sekolah saja sebagai pemimpin, namun juga keterlibatan serta pemberdayaan seluruh sumber daya manusia yang ada dalam sekolah tersebut (Andriani, 20I4). 
Seiring dengan perkembangan teknologi dan ilmu pengetahuan, sekolah diharapkan fleksibel menggapai perubahan ini. Kebutuhan dan keinginan pelanggan juga akan berubah. Menjawab tantangan ini, sekolah perlu mengadakan analisis secara berkelanjutan dengan perubahan kebutuhan pelanggan. Dampaknya untuk sekolah adalah dengan adanya perubahan dala berbagai bidang, kebutuhan pelanggan untuk dipuaskan keinginanya juga akan tinggi. Di sini lah sekolah dituntut untuk dapat mengembangkan sistem pendidikan di sekolah tersebut sesuai dengan harapan pelanggan. Peningkatan mutu peserta didik melalui program teaching factory sebagai upaya untuk menciptakan peserta didik yang mandiri dan memiliki kinerja tinggi untuk dapat bekerja dan dapat bersaing di dunia kerja.

Berdasarkan gambar di atas, metode six sigma yang mendukung perbaikan sistem pendidikan di sekolah dipandang mampu untuk membentuk sekolah yang berbudaya mutu. Integrasi metode six sigma dapat dijadikan pedoman untuk melaksanakan teaching factory guna meningkatkan mutu peserta didik. Hasil analisis dapat dikatakan bahwa sekolah sudah menerapkan metode six sigma sebagai salah satu upaya untuk meningkatkan mutu. Oleh karena itu,sekolah perlu melakukan pengembangan dan pembiasaan sebagai langkah awal. Pembiasaan yang dilakukan nanti akan membentuk suatu budaya mutu yang bila dihubungkan dengan mutu, maka budaya mutu ialah pembiasaan dan kegiatan-kegiatan yang dilakukan secara terusmenerus dan berkelanjutan yang mengarah pada peningkatan mutu.

\section{KESIMPULAN}

Lembaga pendidikan SMK yang berlokasi di Kecamatan Klojen ini merupakan salah satu sekolah kejuruan yang menggunakan program pembelajaran teaching factory sebagai suatu upaya untuk meningkatkan mutu peserta didik. Berdasarkan dari hasil analisis dengan menggunakan metode six sigma, sekolah sebenarnya sudah mengimplementasikan konsep dari TQM. Hanya saja, sekolah secara konteks tidak menjelaskan jika peningkatan mutu yang dilakukan sudah menerapkan metode six sigma. Jika sekolah bersedia dan mampu mengaplikasikan dengan benar metode six sigma dalam setiap kegiatan peningkatan mutu yang dilakukan, maka tidak hanya sekolah dapat memenuhi indikator standar mutu yang telah ditetapkan, namun bisa menggunakan metode six sigma untuk menciptakan budaya mutu sekolah. Metode six sigma ini bisa ditempuh melalui lima tahap yaitu define, measure, analyze, improve dan control. Yang dalam tahap tersebut perlu keterlibatan dan dukungan dari seluruh warga sekolah mulai dari kepala sekolah, guru dan staf, peserta didik, wali murid, masyarakat, stake holder, dan perusahaan kerjasama.

\section{Saran}

Berbicara mengenai peningkatan mutu tidak terlepas dari keterlibatan seluruh anggota organisasi. Peran dan komitmen seluruh pihak untuk meningkatkan mutu sekolah sebagai suatu budaya menjadi dukungan yang positif. Kepala sekolah sebagai pemimpin harus mampu mengikutsertakan seluruh anggotanya untuk terlibat langsung dalam peningkatan mutu sekolah. Perbaikan terus menerus dala pengembangan pembelajaran di sekolah perlu dilakukan. Di sisi lain pihak yang terlibat seperti guru, staf, peserta didik (internal) dan wali murid, masyarakat, perusahaan kerjasama (eksternal) juga menjadi komponen penting dalam keberhasilan proses peningkatan mutu peserta didik. Sekolah diharapkan dapat memaksimalkan tools mutu dan mengembangkan kualitas mutu peserta didik menggunakan konsep dan prinsip dari TQM untuk hasil mutu yang maksimal. Tentunya, tools dan metode yang digunakan disesuaikan dengan prioritasbidang peningkatan mutu yang menjadi fokus dan disesuaikan dengan kebutuhan pelanggan. 


\section{DAFTAR RUJUKAN}

6sigma. (2018). Six Sigma Improbement of Total Quality Management (TQM). Dari https://www.6sigma.us/process-improvement/six-sigma-improvement-total-qualitymanagement-tqm/.

Anderson, R. Et all. (2006). Similarities and Differences Between TQM, Six Sigma, and Lean. The TQM Magazine. 18 (3).

Andriani, G. (20I4). Peningkatan Budaya Mutu untuk Pencapaian Akreditasi di Sekolah Dasar Widoro Yogyakarta. Skripsi tidak diterbitkan. Yogyakarta: Fakultas Ilmu Pendidikan Universitas Negeri Yogyakarta.

Antony, J. (2006). Six Sigma For Service Process. Business Process Journal. 12 (2).

As'ari, D. 2003. Pengembangan Model Kurikulum Berbasis Kompetensi Sekolah Menengah Kejuruan: Studi pada SMK Program Keahlian Teknik Mesin Perkakas. Disertasi Doktor pada Program Pascasarjana UPI Bandung. Tidak diterbitkan.

Dahlgaard, J.J \& Dahlgaard Park, S.M. (2006). Lean Production, Six Sigma, TQM and Company Culture. The TQM Magazine. 18 (3).

Devane, T. (2004). Integrating Lean Six Sigma and High Performance Organizations. San Fransisco: Pfeiffer/ A Willey Imprint.

Direktorat Pembinaan Sekolah Menengah Kejuruan. (2008). Roadmap pengembangan SMK 2010-20/4. Jakarta: Depdiknas.

Farooq, M.S, dkk. (2007). Application Of Total Quality Management In Education. Journal of Quality and Technology Management. (Online). 3 (2). Dari https://www.researchgate.net/publication/234559063_Application_of_Total_Quality_ Management_in_Education.

Hidayat, Dadang. (20II). Model Pembelajaran Teaching Factory Untuk Meningkatkan Kompetensi Siswa Dalam Mata Pelajaran Produktif. Jurnal Ilmu Pendidikan, Vol I7, No 4.

Kaufman, R. (1992). The Challenge of Total Quality Management in Education. International Journal of Education Reform. I(2).

Kementerian Pendidikan dan Kebudayaan. (20I5). Seminar LKS SMK 20I5: Perlunya Sekolah Kejuruan Kembangkan Teaching Factory. Dari. https://www.kemdikbud.go.id/main/blog/20I5/06/seminar-lks-smk-20I5-perlunyasekolah-kejuruan-kembangkan-teaching-factory-4283-4283-4283.

Kementerian Pendidikan dan Kebudayaan. (2016). Grand Design Pengembangan Teaching Factory dan Technopark di SMK. Dari http://repositori.kemdikbud.go.id/5045/I/DjzUYFjnZLI m58GaC5wH0pK4944YS2JWi Oi20Mag.pdf.

Nawawi. H. 2005. Manajemen Strategik.Yogyakarta: Gajah Mada Pers.

Nurtanto, Muhammad, dkk. (2017). Pengembangan Model Teaching Factory di Sekolah Kejuruan. Prosiding Seminar Nasional Pendidikan. ISBN 978-602-194II-2-6. Dari http://webcache.googleusercontent.com/search?q=cache:9saAhEXUFys]:jurnal.untirta.a c.id/index.php/psnp/article/view/447-454+\&cd=2\&hl=en\&ct=clnk\&gl=id.

Purwana, B. H. (2010). Penerapan Desain Kurikulum Sistemik Untuk Mengembangkan Kurikulum Program Produktif Sekolah Menengah Kejuruan. Manajerial. 8 (16). Dari http://repository.upi.edu/id/eprint/I082.

Salah, Souraj \& Carretero, Juan. A. (2009). Six Sigma and Total Quality Management (TQM): similariteis, differences, and relationship. Int. J. Six Sigma and Competitive Advantages. 5 (3).

Dari https://www.researchgate.net/publication/239433605_Six_Sigma_and_Total_Quality_ Management_TQM_similarities_differences_and_relationship.

Sallis, E. (2006). Total Quality Management in Education. Penerjemah Ahmad Ali Riyadi. Yogyakarta: IRCiSoD. 
Skaneda. (2018). Teaching Factory (TEFA). Dari https://smkn2negara.sch.id/read/28/teachingfactory-tefa.

Stroud-Friday \& Sutterfield, J.S. (2007). A Conceptual Framework for Integrating Six Sigma and Strategic Management Metodhologies to Quantity Decision Making. The TQM Magazine. 19 (6).

Villanova University. (20I5). Six Sigma in Education. Dari https://www.villanovau.com/resources/six-sigma/in-education/. 